\title{
Effect of androgens on the development of mouse follicles growing in vitro
}

\author{
A. A. Murray ${ }^{1}$, R. G. Gosden ${ }^{2}$, V. Allison ${ }^{1}$ and N. Spears ${ }^{1 *}$ \\ ${ }^{1}$ Department of Physiology, University Medical School, Teviot Place, Edinburgh EH8 9AG, UK; and \\ ${ }^{2}$ Division of Obstetrics and Gynaecology, University of Leeds, Clarendon Wing, Leeds General InArmary, \\ Leeds LS2 9NS, UK
}

\begin{abstract}
The effects of androgens on ovarian follicular development have been investigated using a whole follicle culture system. Follicles obtained from mouse ovaries and cultured in the presence of anti-androgen serum grew more slowly than control follicles. This effect was reversed by the addition of androstenedione to the medium. A similar effect was obtained when receptor-mediated effects of androgens were blocked using an androgen receptor antagonist. When follicles were grown in concentrations of FSH that are marginal for follicle development, they developed faster in the presence of a non-aromatizable androgen, dihydroxytestosterone. The results indicate that androgens exert a direct, stimulatory role on the growth and development of mouse antral follicles, in vitro.
\end{abstract}

\section{Introduction}

Although gonadotrophins are the primary factors regulating ovarian follicular development, it has become increasingly clear that the effects of FSH and LH are modulated by a variety of paracrine and autocrine factors. The recent discovery of developmentally regulated androgen receptors on the granulosa cells of growing, rat and primate follicles (Tetsuka et al., 1995; Tetsuka and Hillier, 1996; Hillier et al., 1997) indicates that androgens could have direct effects on the development of ovarian follicles, in addition to indirect effects resulting from oestradiol production after aromatization in the granulosa cells. Spears et al. (1998) showed that aromatizable androgens stimulated follicle development in vitro, whereas oestradiol had no observable effect, raising the possibility that the stimulatory effect of the androgens is due to its direct action on the follicle.

Studies in vivo have shown contradictory effects of androgens, some of which seemed to show stimulatory effects on follicular development (for example, Hillier and Ross, 1979) while others indicated inhibition (Farookhi, 1985). However, experiments with $\mathrm{Tfm} / \mathrm{O}$ (testicular feminization) mice, which are unable to respond to androgens, have demonstrated that androgens are not essential for follicular development (Lyon and Glenister, 1974). Studies of ovarian cell lines in vitro have indicated an atretogenic effect of androgens (Jia et al., 1985), although cultures of single cell types overlook the potential physiological significance of the influences of other follicular cell types.

We have addressed the question of whether androgens have modulatory effects in promoting follicular development by using a follicle culture system in which individual follicles can be grown from the late preantral to the Graafian stage. The merit of this culture system is that the growth and develop-

*Correspondence.

Revised manuscript received 7 August 1997 ment of the follicles in vitro appears to mimic that of maturation in vivo (Gosden et al., 1993; Boland et al., 1993; Spears et al., 1994). The culture system allows the possibility that androgens exert a direct effect on follicular growth or differentiation to be examined in a highly controlled, but none the less physiological environment, while excluding the possibility of confounding extra-ovarian factors.

\section{Materials and Methods}

\section{Animals}

Twenty-four-day-old C57BL/6 $\times \mathrm{CBA} / \mathrm{Ca} \mathrm{F}_{1}$ hybrid, female mice were housed in a temperature- and light-controlled room on a $14 \mathrm{~h}$ light: $10 \mathrm{~h}$ dark photoperiod and provided with food and water ad libitum. Female hypogonadal mice (hpg/hpg) produced by mating heterozygous parents were selected on the basis of phenotype and maintained under similar conditions.

\section{Follicle isolation and culture}

The mice were killed by cervical dislocation and their ovaries removed to watchglasses containing Leibovitz L-15 medium (Gibco-BRL, Irvine) and $3 \mathrm{mg} \mathrm{BSA} \mathrm{m}^{-1}$ (Fraction V, Sigma, Poole) at $37^{\circ} \mathrm{C}$. Preantral mouse follicles (diameter $185 \pm$ $15 \mu \mathrm{m})$ were isolated by microdissection using fine needles and pipetted individually to $\mathrm{V}$-wells of microtitre plates in $20 \mu \mathrm{l}$ $\alpha$-minimal essential medium (Bibby-Sterilin Ltd, Stone, Staffordshire; Gibco-BRL, Renfrew) under $50 \mu 1$ mineral oil according to Boland et al. (1993), based on an earlier, similar method (Nayudu and Osborn, 1992). The medium was supplemented with $10 \mu g$ human transferrin $\mathrm{ml}^{-1}$ (Sigma) and $5 \%$ serum from the hypogonadal mice. Gonadotrophins were added to some 


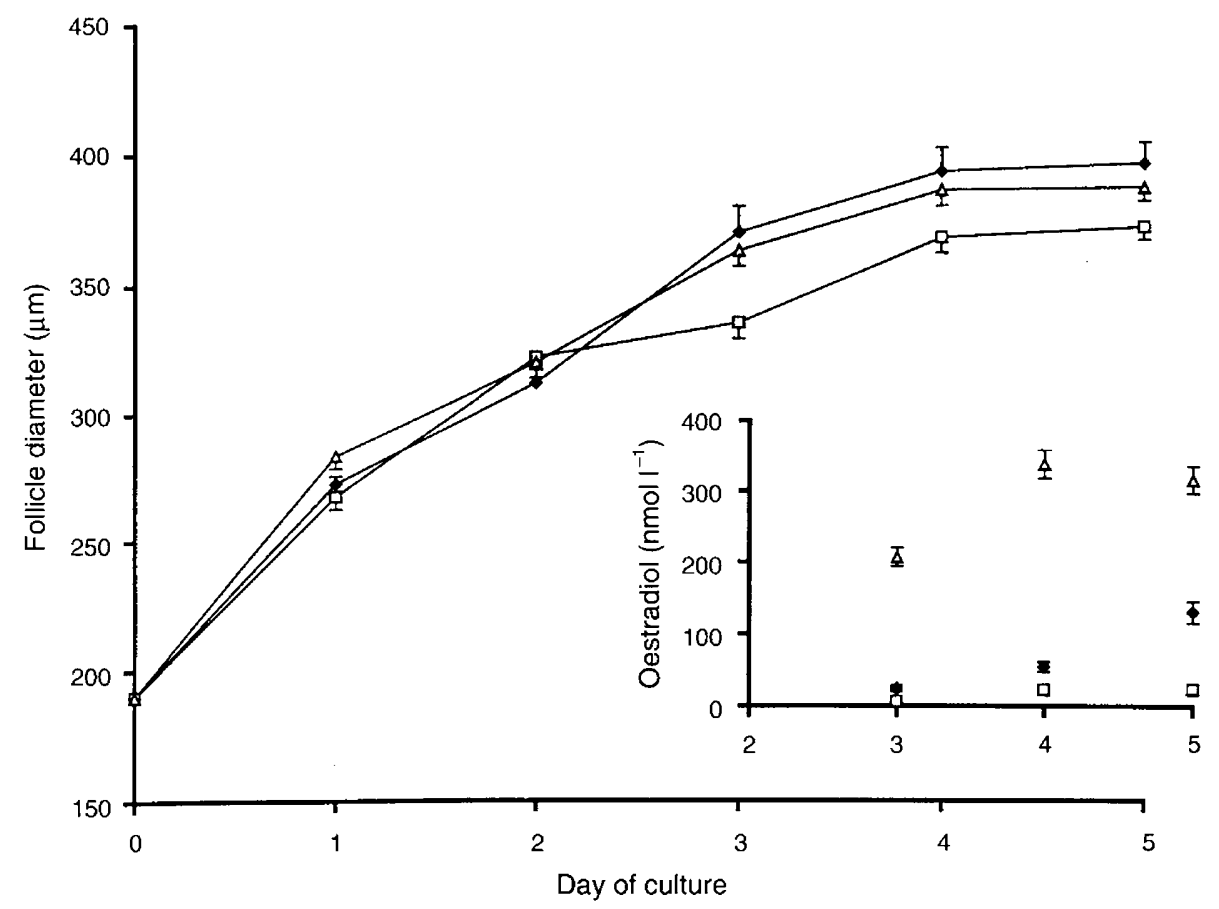

Fig. 1. Variation in the rates of growth of and (inset) production of oestradiol by mouse follicles grown in vitro for 5 days from the preantral stage. The effects of antibodies to androgens and replacement treatment with androstenedione are compared. ( $\bullet$ Control; $(\square)$ anti-androgen antibody; $(\triangle)$ anti-androgen antibody plus androstenedione. Treatment began $24 \mathrm{~h}$ after establishing the cultures.

of the wells at a concentration of either 1 or $5 \mathrm{iu} \mathrm{ml} \mathrm{ml}^{-1}$. The gonadotrophins used were either human pituitary FSH (NIH-FSH, National Hormone and Pituitary Program, Bethesda, MD), which contained approximately $1 \% \mathrm{LH}$ as an impurity, or recombinant human FSH (rFSH) (Serono Laboratories, Geneva).

\section{Measurement of oestradiol}

After transfer of the follicles, a sample of medium from the previous day's incubation was removed from each well and analysed immunoenzymatically for oestradiol using an ELISA method (Serono Diagnostics, Woking, Surrey). The interand intra-assay coefficients of variation were $\leq 5 \%$ and the sensitivity was $\leq 18 \mathrm{pmol}^{-1}$.

\section{Growth and morphology of follicles}

Follicular growth was monitored by measuring the diameter of follicles on each day of culture using a precalibrated ocular micrometer at $\times 40$ magnification. Data presented includes measurements from all follicles still viable on the final day of culture. About $20 \%$ of follicles burst or became atretic, usually early in the culture period (probably due to damage on the day of dissection). No measurements from such follicles were included in the analyses. No differences were found in the percentage of such follicles across treatments.
In Expt 1, DNA accumulation by preovulatory follicles on day 5 of culture was also assessed using a fluorescent dye, Hoechst 33258 (Sigma) (bisbenzimidazole: Boland and Gosden, 1994).

The number of preovulatory follicles and the total number of follicles at different antral stages were recorded at the end of each culture period. Preovulatory follicles were classified as having (i) a diameter $\geq 400 \mu \mathrm{m}$; (ii) a large antral cavity; (iii) an eccentrically placed cumulus-oocyte complex; (iv) no signs of atresia (dark patches of dead cells within the membrana granulosa). Mid-antral follicles included all follicles with a clearly defined cavity and without signs of atresia, while early-antral follicles exhibited only the initiation of antral development, as viewed under a dissecting microscope.

\section{Experiment 1: effects of androgen antibody on follicular development}

Anti-androgen antibodies were used to neutralize androgens secreted by cultured follicles or present in the mouse serum. The high-titre antiserum was raised by immunizing castrated Suffolk cross-bred sheep with testosterone-3-carboxymethyloxime conjugated to egg albumin (Land et al., 1982). There was significant crossreaction of the antibody with androstenedione $(0.9 \%)$, androsterone $(3.3 \%)$, dihydroxytestosterone (DHT) $(12.1 \%)$ and testosterone (100\%), but not with either oestrogens or progestagens (Webb et al., 1985).

Thirty preantral follicles were dissected for each experiment and allocated randomly to groups, as follows. Ten follicles were exposed to $3 \%$ anti-androgen serum from day 1 to day 5 


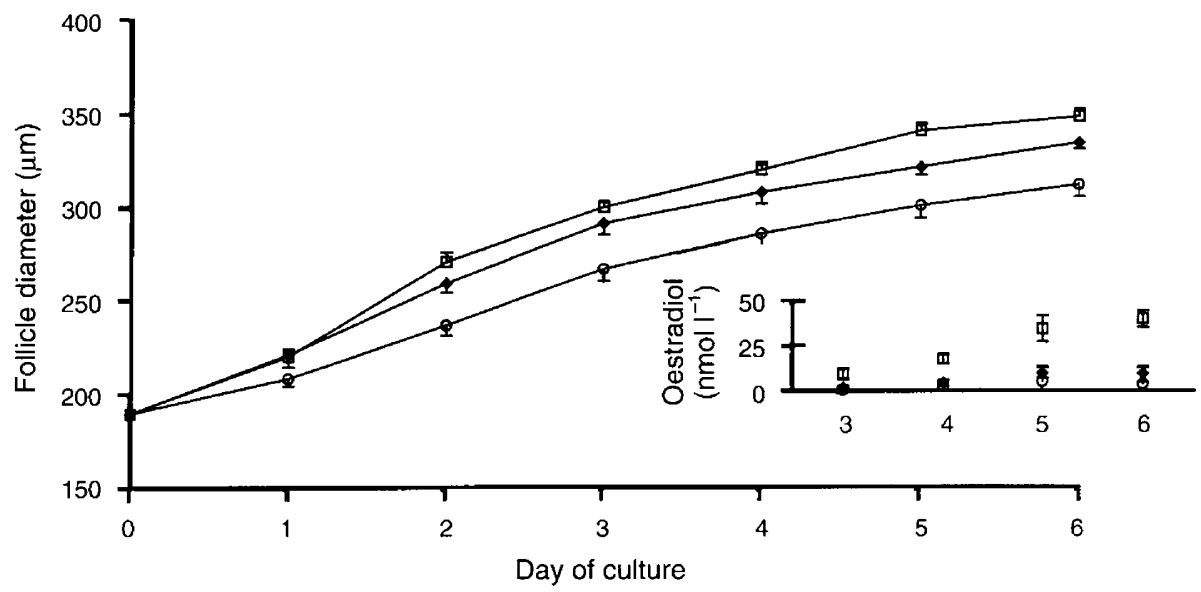

Fig. 2. Growth rates of and (inset) oestradiol output by mouse follicles cultured in medium containing recombinant human FSH and ( $\square$ ) $1 \mu \mathrm{l}$ dimethyl sulfoxide (DMSO) $\mathrm{ml}^{-1}$, or where Casodex $\left((\diamond) 1 \times 10^{-5}\right.$ or $\left.(O) 1 \times 10^{-4.5} \mathrm{~mol} \mathrm{l}^{-1}\right)$ dissolved in $1 \mu \mathrm{DMSO} \mathrm{ml}{ }^{-1}$ was added to the medium.

of culture. A further 10 follicles were cultured with the same serum with an excess of $1 \mu \mathrm{g}$ androstenedione $\mathrm{ml}^{-1}$ to overwhelm any effects of the antibody. The other 10 follicles were cultured in control medium containing the same percentage of normal sheep serum without androstenedione. The sera had been heat-inactivated for $30 \mathrm{~min}$ at $56^{\circ} \mathrm{C}$ before culture, which leaves antibody activity undiminished, but destroys complement activity. All follicles were cultured in the presence of 1 iu NIH-FSH ml ${ }^{-1}$.

\section{Experiment 2: effects of an androgen receptor antagonist}

Follicles were cultured with $\mathrm{rFH}$ ( $5 \mathrm{iu} \mathrm{ml}^{-1}$ ) plus dimethyl sulfoxide (DMSO) $\left(1 \mu \mathrm{l} \mathrm{ml}{ }^{-1}\right)$ alone, or with the addition of $1 \times 10^{-5}$ or $1 \times 10^{-4.5}$ mol Casodex $1^{-1}$ (bicalutamide: ICI 176,334; Zeneca, Macclesfield, Cheshire), an androgen receptor antagonist, solubilized in $1 \mu \mathrm{I}$ DMSO $\mathrm{ml}^{-1}$ medium. Follicles were measured and transferred to fresh medium each day. Media were collected for oestradiol analysis on days 3, 4, 5 and 6 of culture, and on the final day of culture (day 6), follicles were scored for stage of antral development.

\section{Experiment 3: effects of non-aromatizable androgens}

Follicles were cultured in 0.5 iu $\mathrm{rFSH} \mathrm{ml}^{-1}$ (marginally adequate for follicle growth) to allow only limited follicular development, in the presence or absence of the nonaromatizable androgen DHT dissolved in $1 \mu \mathrm{l}$ ethanol $\mathrm{ml}^{-1}$. Control follicles were cultured in $5 \mathrm{iu} \mathrm{rSSH} \mathrm{ml}{ }^{-1}$ plus or minus $1 \mu \mathrm{l}$ ethanol $\mathrm{ml}^{-1}$ medium. Follicles were measured and transferred to fresh medium daily. Media were collected and analysed for oestradiol on days 4,5 and 6 of culture, and on the final day (day 6) follicles were scored for the stages of antral development.

\section{Histological preparations}

Cultured follicles were prepared for examination by light microscopy after fixing overnight in 5\% paraformaldehyde.
Follicles were then embedded in LR White resin (Taab, Aldermaston) and $2 \mu \mathrm{m}$ sections were cut and stained with haematoxylin and eosin.

\section{Statistical analyses}

Each experiment was repeated three times, with the exception of Expt I which was performed in duplicate. Probability values $(P)$ between the different groups were determined by the unpaired Student's $t$ test and analysis of variance.

\section{Results}

\section{Experiment 1: effects of anti-androgen antiserum}

There was no significant difference in size between follicles cultured with or without anti-androgen serum during the first 2 days of preantral development (Fig. 1). However, there was a slight, but nevertheless significant, slowing of growth during the later days of culture in the group treated with antiserum $(P<0.05)$. This trend was reversed when androstenedione was added to the medium. These differences were reflected in the DNA assays. Follicles that were untreated, or received the double supplement, contained $700 \pm 30$ and $695 \pm 26 \mathrm{ng}$ DNA per follicle, respectively, whereas those receiving the antiserum alone contained significantly less $(550 \pm 23 \mathrm{ng})$ DNA per follicle $(P<0.02)$.

Oestradiol production by follicles cultured with the antiserum was substantially reduced on days 3,4 and 5 , when normally it is increasing steeply $(P<0.05)$. Addition of androstenedione significantly increased oestradiol production above that in control follicles on each of these days $(P<0.01)$ (Fig. 1).

\section{Experiment 2: effects of androgen receptor antagonist}

Follicles cultured in the presence of Casodex were significantly less well developed than those cultured in its absence: increasing concentrations of Casodex produced follicles with 

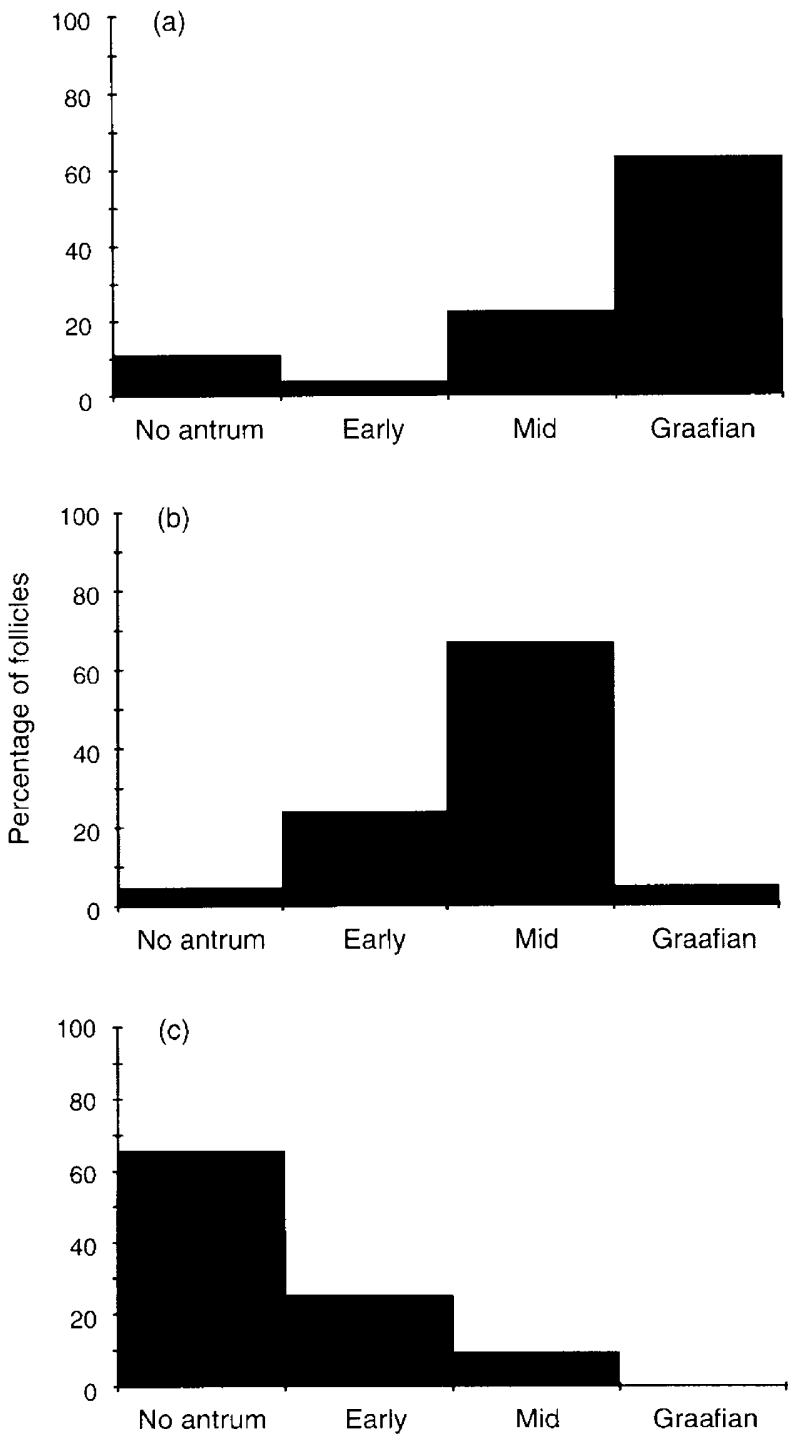

Fig. 3. Antral development of mouse follicles on the final day of culture after treatment with (a) dimethyl sulfoxide (control); (b) Casodex $\left(1 \times 10^{-5} \mathrm{~mol} \mathrm{l}{ }^{-1}\right)$ or $(\mathrm{c})$ Casodex $\left(1 \times 10^{-4.5} \mathrm{~mol} \mathrm{l}-1\right)$.

increasingly suppressed growth curves and oestradiol output (Fig. 2); antral cavities at the end of the culture period were also less developed (Fig. 3). The presence of DMSO at low concentrations had no effect on follicular development.

\section{Experiment 3: effects of non-aromatizable androgens}

Follicles cultured in low concentrations of FSH grew significantly less well than control follicles cultured with a higher FSH concentration. When DHT was added to the culture medium, follicular growth and antral development were restored to near normal, while oestradiol output remained low (Figs 4, 5 and 6). Ethanol (in which the DHT was solublized) had no effect on follicle development when added at the same concentration (Fig. 5).

\section{Discussion}

The effect of androgens on follicular growth and development has been unclear, with much of the literature contradictory.
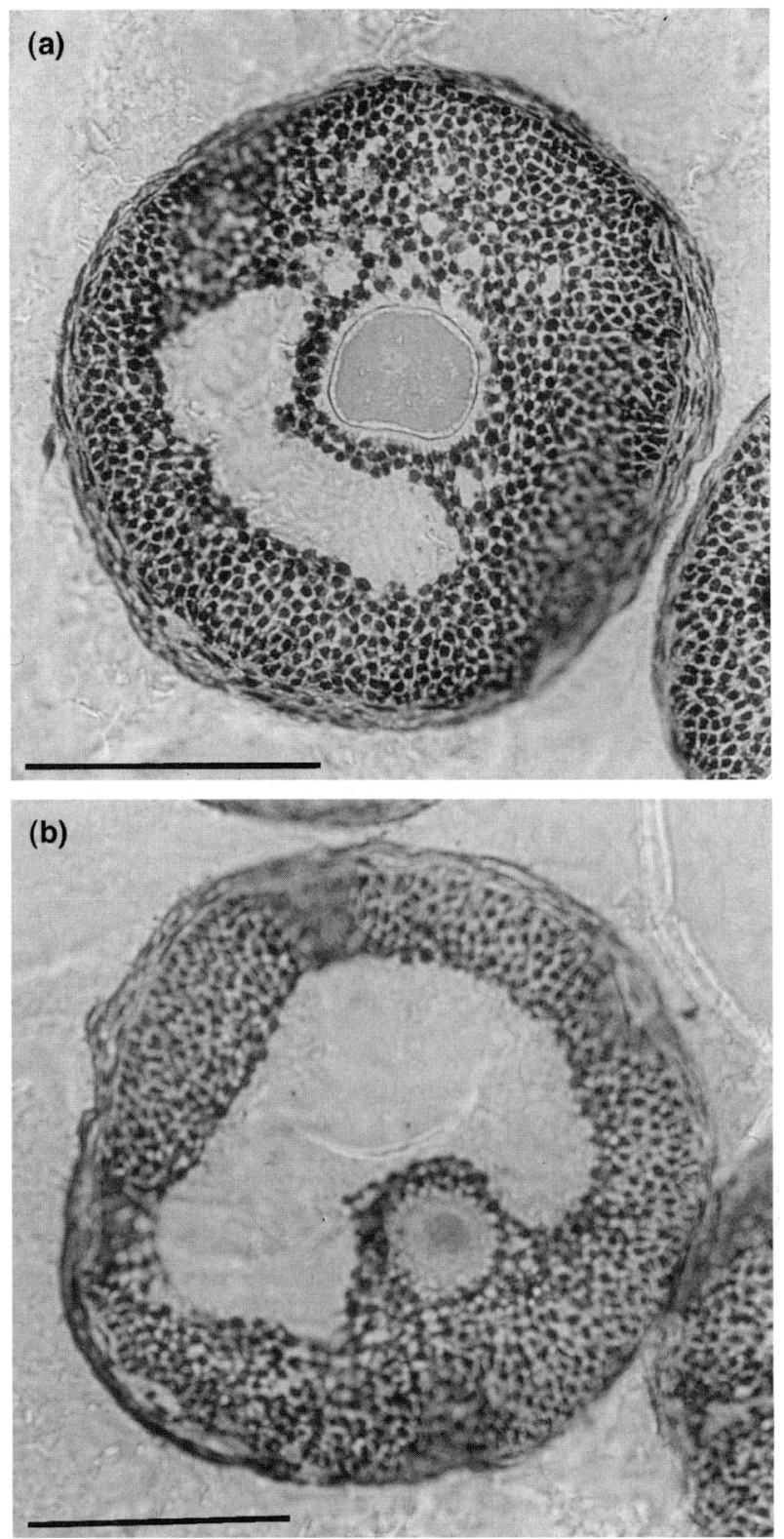

Fig. 4. Photomicrographs of (a) a mouse follicle cultured in low concentrations of recombinant human FSH ( $\mathrm{rFSH}$ ) only and (b) a mouse follicle cultured in a system in which low concentrations of rFSH were supplemented with dihydroxytestosterone. Scale bar represents $100 \mu \mathrm{m}$.

Approaching the question from three distinct angles, we have shown in the work presented here that the development of intact mouse follicles in vitro is stimulated by androgens. Spears et al. (1998) found that androstenedione, an aromatizable androgen, stimulated follicular growth as well as oestradiol output in vitro. Although the effect of follicular growth could have been due to the increased oestrogen secretion by these follicles, this interpretation seemed unlikely based on the lack of effect of either oestrogen antibodies or oestrogen receptor antagonists.

In view of the presence of androgen receptors in granulosa cells of growing follicles (Tetsuka et al, 1995), it is quite 


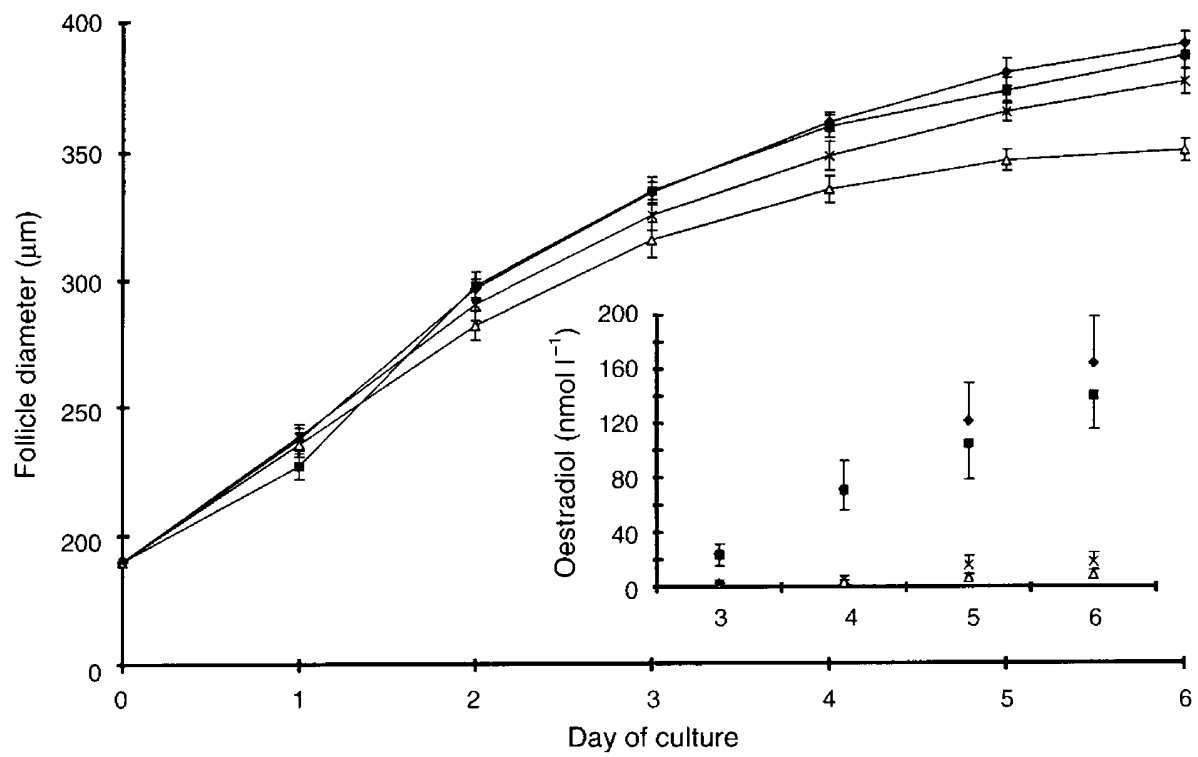

Fig. 5. Growth rates of and (inset) oestradiol output by mouse follicles cultured in $(\downarrow) 5$ iu recombinant human FSH $(\mathrm{rFSH}),(\boldsymbol{\square}) 5 \mathrm{iu} \mathrm{rFSH}$ plus $1 \mu \mathrm{l}$ ethanol $\mathrm{ml}^{-1},(\triangle) 0.5 \mathrm{iu} \mathrm{rFSH}$ or $(x)$ $0.5 \mathrm{iu} \mathrm{rFSH}$ supplemented with $1 \mu \mathrm{g}$ dihydroxytestosterone $\mathrm{ml}^{-1}$.

plausible that these steroids have a paracrine action in controlling growth. The experiments described here reveal an effect of androgens on whole ovarian follicles in vitro that was shown to be due, in part at least, to a direct action of the androgens. Follicular development was depressed by the addition of an androgen receptor antagonist, and by an androgen antibody, the latter effect being reversed by the addition of excess androgen, which neutralized the effects of the antibody by competition. Similarly, follicular development was stimulated by the addition of non-aromatizable androgens, confirming a direct effect of androgens rather than via aromatization to oestrogen.

Since antibodies act extracellularly, any ability of antiandrogens to reduce oestradiol production indicates that androgens had been prevented from passing from one cell to another for aromatization to oestrogen. The profound reduction of oestradiol production in vitro, therefore, substantiates the two-cell theory for the mouse and is in agreement with comparable studies that have been carried out in vivo in other species (Baird, 1977) and in vitro using co-cultures of granulosa and theca-interstitial cells (Lui and Hsueh, 1986). The present work showed evidence of an intrafollicular role of androgens. Antibodies to these steroids produced a slower rate of follicle growth during the early stages of Graafian development, which was reversible with androstenedione supplementation. Although oestrogen concentrations were reduced in these experiments, the results of Spears et al. (1998) indicate that it is unlikely that oestrogen is responsible for these effects on follicle growth.

The androgen-receptor antagonist, Casodex, inhibits the ability of androgens to influence follicle development via receptor binding, without affecting aromatization to oestrogen, or altering the potential for oestrogen to alter follicular development. Follicles treated with increasing doses of Casodex exhibited increasing inhibition of follicular development and oestrogen secretion. Follicles treated with Casodex had greatly diminished antral development by the end of the culture period, and oestradiol output was commensurate with their retarded development. This effect of Casodex appears to be due to arrested development, rather than a reduced rate of development, as follicles cultured for an additional 2 or 3 days were still unable to develop to the Graafian stage (A. A. Murray, R. G. Gosden, V. Allison and N. Spears, unpublished results).

In the final experiment reported here, follicular development was retarded by culturing the follicles in reduced concentrations of FSH. A concentration of FSH was chosen that supported follicle survival and growth, but that did not promote development to the Graafian stage within the usual culture period. The inadequate development of follicles cultured in the low FSH concentrations could be partially overcome by the addition of a non-aromatizable androgen, DHT, although androgens were unable to stimulate follicular development in the complete absence of FSH (A. A. Murray, R. G. Gosden, V. Allison and N. Spears, unpublished results), presumably due to the vital survival effect of FSH (Chun et al., 1996, Spears $e t$ al., 1998). In this, and the first experiment, in which androgens were added to the culture medium, concentrations were chosen that reflect concentrations in both human and pig follicular fluid (Ding and Foxcroft, 1992; McNatty et al., 1979) since no comparable data are available for rodents.

Tetsuka and Hillier (1996) reported the ability of DHT, in combination with FSH, to stimulate $\mathrm{P} 450$ aromatase and the production of the mRNA encoding the androgen receptor. Ghersevich et al. (1994) have also shown that DHT enhances the stimulatory effect of FSH on the production of $17 \beta$ hydroxysteroid-dehydrogenase by granulosa cells, while the ability of androgens to stimulate follicular development in the presence of low concentrations of oestrogens has been shown in rhesus monkeys using an aromatase inhibitor (ZelinskyWooten et al., 1993). It is of interest that, in the present experiments, oestrogen concentrations did not increase propor- 

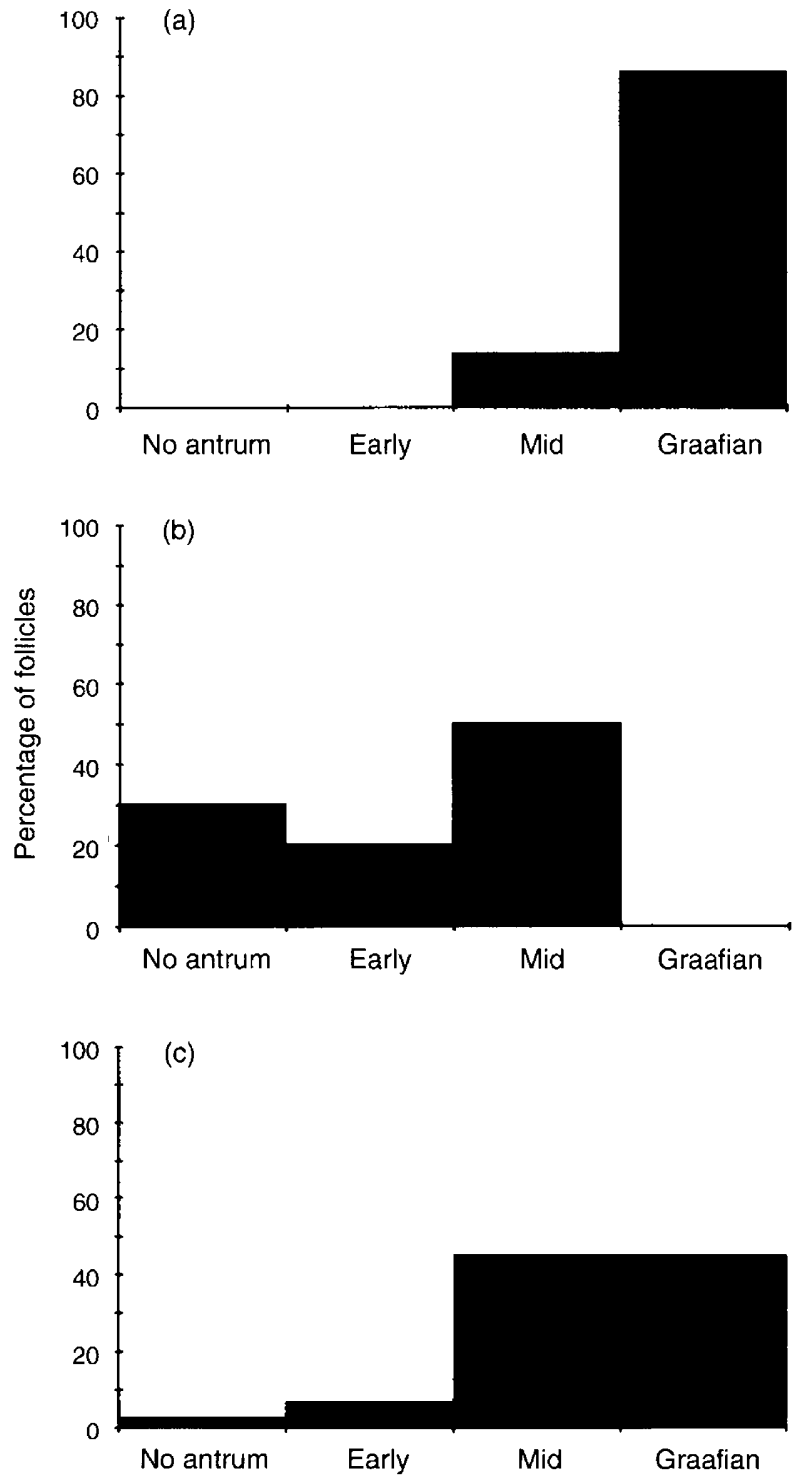

Fig. 6. Antral development of mouse follicles on the final day of culture after treatment with (a) 5 iu recombinant human $\mathrm{FSH}(\mathrm{rFSH})$ plus $1 \mu$ l ethanol $\mathrm{ml}^{-1}$; (b) $0.5 \mathrm{iu} \mathrm{rFSH}$ or (c) $0.5 \mathrm{iu} \mathrm{rFSH}$ supplemented with $1 \mu \mathrm{g}$ dihydroxytestosterone $\mathrm{ml}^{-1}$.

tionately with follicular development in the follicles cultured in the presence of DHT; this is possibly due to the ability of DHT to act as a competitive inhibitor to aromatase, which is known to occur in vitro (Hillier et al., 1980).

The expression of androgen receptors has been shown to be developmentally regulated, with the number of receptors highest in preantral and early antral follicles. There is then an FSH-dependent decrease in numbers of receptors during preovulatory growth (Hillier et al., 1997; Tetsuka and Hillier, 1996), and it is probable that the stimulatory effects of androgens on follicular development are, similarly, transient.

The stimulatory effects of androgens on ovarian development have been known for some time (for example, Schomberg et al., 1976; Hillier and Ross, 1979), but they were often considered to be due to indirect stimulation, via oestrogen. As a result of this possibility, and due to the clear effects of oestrogens in stimulating ovarian development in hypophysectomized rats (Williams, 1940), oestrogens are frequently assumed to stimulate follicular development, whereas androgens are often cited as atretogenic. However, there is now mounting evidence that, in many species, including the mouse, there is no simple causal relationship between the oestrogenandrogen balance within a follicle and developmental fate. Zelinski-Wooten et al. (1993) showed that high androgen: oestrogen ratios in rhesus monkeys do not inhibit follicular development, although fertilization rates of the resulting oocytes were decreased. Oestrogen appears to have little effect on the development of mouse follicles (see Spears et al., 1998), and in the work presented here, we demonstrate a stimulatory role for murine androgens within the developing follicle. It remains to be explained whether the inhibitory effects of androgens shown by others both in vitro (Jia et al., 1985) and in vivo (Billig et al., 1993; Farookhi, 1985; Payne et al., 1956) reflect species differences or extra-ovarian or culture phenomena.

This work was supported by The Royal Society. The authors would like to thank H. M. Charlton and P. O'Shaughnessy for hypogonadal mice, R. Webb for the anti-androgen antibody and C. Wakeling (Zeneca) for the androgen-receptor antagonist. We also gratefully acknowledge gifts of recombinant gonadotrophin hFSH and hLH, from C. Howles (Serono, Geneva). Pituitary FSH (AFP-5720D) was obtained through NHPP, NIDDK, NICHHD, USDA.

\section{References}

Baird DT (1977) Evidence in vivo for the two-cell hypothesis of oestrogen synthesis by the sheep Graafian follicle Journal of Reproduction and Fertility $\mathbf{5 0}$ 183-185

Billig H, Furuta I and Hsueh AJW (1993) Estrogens inhibit and androgens enhance ovarian granulosa cell apoptosis Endocrinology 133 2204-2212

Boland NI and Gosden RG (1994) Effects of epidermal growth factor on the growth and differentiation of cultured mouse ovarian follicles Journal of Reproduction and Fertility $101369-374$

Boland NI, Humpherson DG, Leese HJ and Gosden RG (1993) Pattern of lactate production and steroidogenesis during growth and maturation of mouse ovarian follicles in vitro. Biology of Reproduction 48 798-806

Chun S, Eisenhauer KM, Minami S, Billig H, Perlas E and Hsueh AJW (1996) Hormonal regulation of apoptosis in early antral follicles: FSH as a major survival factor Endocrinology 137 1447-1456

Ding J and Foxcroft GR (1992) Follicular heterogeneity and oocyte maturation in vitro in pigs Biology of Reproduction 47 648-652

Farookhi R (1985) Effects of aromatizable and non aromatizable androgen treatments on $\mathrm{LH}$ receptors and ovulation induction in immature rats Biology of Reproduction 33 363-369

Ghersevich S, Poutanei M, Tapanainen J and Vihko R (1994) Hormonal regulation of rat 17 beta hydroxysteroid dehydrogenase type 1 in cultured rat granulosa cells: effects of $\mathrm{rSH}$, estrogens, androgens and EGF Endocrinology 135 1963-1971

Gosden RG, Boland NI, Spears N, Murray AA, Chapman M, Wade JG, Zohdy N and Brown $N$ (1993) The biology and technology of follicular oocyte development in vitro. Reproductive Medicine Review 2 129-152

Hillier SG and Ross GT (1979) Effects of exogenous testosterone on ovarian weight, follicular morphology and intra ovarian progesterone concentration in estrogen-primed hypophysectomized immature female rats Biology of Reproduction $20261-268$

Hillier SG, Van der Boogaard AMJ, Reichert LE and Van Hall EV (1980) Alterations in granulosa cell aromatase activity accompanying preovulatory follicular development in the rat ovary with evidence that 5 -alpha-reduced C19 steroids inhibit the aromatase reaction in vitro. Journal of Endocrinology $84 \quad 409-419$ 
Hillier SG, Tetsuka M and Fraser HM (1997) Location and developmental regulation of androgen receptor in primate ovary Human Reproduction 12 $107-111$

Jia C, Kessel B, Welsh TH and Hsueh AJW (1985) Androgen inhibition of FSH stimulated LH receptor formation in cultured rat granulosa cells Endocrinology $11713-22$

Land RB, Morris BA, Baxter G, Fordyce M and Forster J (1982) Improvement of sheep fecundity by treatment with antisera to gonadal steroids Journal of Reproduction and Fertility 66 625-634

Lui Y-X and Hsueh AJW (1986) Synergism between granulosa and thecainterstitial cells in oestrogen biosynthesis by gonadotrophin-treated rat ovaries: studies on the two-cell, two-gonadotrophin hypothesis using steroid antisera Biology of Reproduction 35 27-36

Lyon MF and Glenister PH (1974) Evidence from Tfm/o that androgen is inessential for reproduction in female mice Nature 247 366-367

McNatty KP, Markris A, de Grazia D, Osathanondh R and Ryan KJ (1979) The production of progesterone androgens and oestrogens by human granulosa cells in vitro and in vivo. Journal of Steroid Biochemistry 11 775-779

Nayudu PL and Osborn SM (1992) Factors influencing the rate of preantral and antral growth of mouse ovarian follicles in vitro. Journal of Reproduction and Fertility 95 349-362

Payne RW, Hellbaum AA and Owens JN (1956) The effect of androgens on the ovaries and uterus of the estrogen-treated hypophysectomized immature rat Endocrinology 59 306-316

Schomberg DW, Stouffer RL and Tyrey L (1976) Modulation of progestin secretion in ovarian cells by dihydrotestosterone: a direct demonstration on monolayer culture Biochemistry and Biophysiology Research Communication 68 $77-81$
Spears N, Boland NI, Murray AA and Gosden RG (1994) Mouse oocytes derived from in vitro grown primary ovarian follicles are fertile Human Reproduction $9527-532$

Spears N, Murray AA, Allison V, Boland NI and Gosden RG (1998) Role of gonadotrophins and ovarian steroids in the development of mouse follicles in vitro. Journal of Reproduction and Fertility $\mathbf{1 1 3} 19-26$

Tetsuka M and Hillier SG (1996) Androgen receptor gene expression in rat granulosa cells: the role of FSH and steroid hormones Endocrinology 137 4392-4397

Tetsuka M, Whitelaw PF, Bremner WJ, Millar MR, Smyth CD and Hillier SG (1995) Developmental regulation of androgen receptor in rat ovary Journal of Endocrinology 145 535-543

Webb R, Baxter G, McBride D, Nordblom GD and Shaw MPK (1985) The measurement of testosterone and oestradiol-17ß using iodinated tracers and incorporating an affinity chromatography extraction procedure Journal of Steroid Biochemistry 23 1043-1051

Williams PC (1940) Effect of stilboestrol on the ovaries of the hypophysectomized rat Nature $145388-389$

Zelinski-Wooten MB, Hess DL, Boughman WL, Molskness TA, Wolf DP and Stouffer RL (1993) Administration of an aromatase inhibitor during the late follicular phase of gonadotropin-treated cycles in rhesus monkeys: effects of follicle development, oocyte maturation and subsequent luteal function Journal of Clinical Endocrinology and Metabolism 76 988-995 